Research Article

\title{
ROLE OF SALICYLIC ACID ON GROWTH, YIELD, QUALITYAND DISEASE PEST REACTION OF ONION (ALLIUM CEPAL.) CV. AGRIFOUND LIGHT RED
}

\author{
P. Bhasker ${ }^{*}$, P.K. Gupta and H.P. Sharma
}

Department of Plant Physiology, National Horticultural Research and Development Foundation, Chitegaon Phata, Nashik, Maharashtra, India

\begin{abstract}
Salicylic acid (SA) is endogenous naturally occurring plant growth hormone acting as an important signaling molecule adds tolerance against abiotic stress. A field experiment was conducted to assess the efficacy of exogenous application of SA on growth, yield and storage performances of onion during Rabi 2012-13, 2013-14 and 2014-15. The experiment was comprised of 6 different treatments of SA including control. Exogenous applications of all SA treatments significantly influenced plant growth and development. The treatment application of SA at 30 days after seed sowing and second spray at 30 days after transplanting and third spray at 60 days after transplanting performed superior in terms of growth, development and yield. Exogenous application of SA significantly influenced on thrips population and stemphylium blight disease incidence and intensity. The results also revealed that SA partially involved in post-harvest management of onion.
\end{abstract}

Keywords: Foliar application, Insect, Onion, Post-harvest storage, Salicylic acid

\section{INTRODUCTION}

Onion (Allium cepa L.) is one of the most important commercial vegetable crops grown in India. The highest foreign exchange earner with higher medicinal as well as consumption values (Bhasker et al., 2018) among all the vegetable crops. India ranks second in area as well as in production in the world after China. Thearea and production of onion in India is 11,81,000 hectares and 18,9,24,000 tons, respectively, with an average yield of $16 \mathrm{t} \mathrm{ha}^{-1}$ (National Horticultural Board, 2017). The lower productivity is due to cultivation of low yielding potential of open pollinated conventional varieties which are susceptible to biotic factors and includes bacteria,

\footnotetext{
*Corresponding author: bhasker_hau@yahoo.co.in
} 
fungi, viruses, insects, and abiotic factors i.e. drought, salinity, heat, cold and heavy metal stress. Plants have evolved broad and efficient self-mechanisms to cope with these continuous adverse challenges and to obtain an adequate defense mechanism against biotic and abiotic constrains (Nazar et al., 2011). Plants have a prominent defensive response against biotic (pathogen) attack by the synthesis of low molecular compounds with disparate functions in pathogen interactions of plant (Dixon, 2001).

Salicylic Acid (SA) (2-hydroxybenzoic acid), is recently included in the category of plant growth hormones. It is an important signal molecule belonging to an extra ordinary diverse group of plant phenolic compound synthesized under different biotic and abiotic stresses (Vlot et al., 2009; Bideshki and Arvin, 2010; Miura and Tada, 2014; Shama et al., 2016). SA is distributed in wide range of plant species and act as a defensive signal that is essential for elicitor triggered immunity and the establishment of Systematic Acquired Resistance (SAR) by inducing particular enzymes involved in biosynthetic reactions (Carr et al., 2010). Thus, SA is an endogenous growth regulator, which participates in regulation of several physiological processes in crop plants viz., closing of stomata, induction of flower, ion uptake, inhibition of ethylene biosynthesis and transpiration (Khan et al., 2003; Hayat et al., 2009) and it also involved in reverses the effects of ABA on leaf abscission by this ameliorates the growth of crop.SA promotes resistance against several viral, fungal and bacterial pathogens in various crops viz. tomato (He and Zhu, 2008; Pandey and Gupta, 2012) and carrot (Hayat et al., 2009) with a diverse way of defense strategies in which SA play a core role and is the key element in both local and systemic defense, but limited information is available about SA effects on purple blotch (Alternaria porii) and stemphylium blight (Stemphylium vesicarium) in onion. In addition to its role towards biotic stresses, SA is also proved believed to play a key role in plant responses to many abiotic stresses such as heat stress in mustard (Dat et al., 1998), ozone in turnip (Kachroo et al., 2000), drought stress in wheat (Singh and Usha, 2003), mustard (Nazara et al., 2015), soybean (Nasrin et al., 2017) and chilling stress in peach (Zhang et al., 2017). The earlier studies have reported that foliar application of SA play a significant role in plant water relations, photosynthesis (Habibi, 2012; Nazara et al., 2015) including increases in yield in several crops like garlic (Bideshki and Arvin, 2010), brinjal (Gawade and Sirohi, 2011) and tomato (Nigar et al., 2017). There is a limited literature is available of SA role on one of the most important export oriented onion crop. The pre harvest sprays of chemicals such as maleic hydrazide, ethrel, cycocel, carbendazim, benomyl, streptocycline treatments widely applied without impairing the keeping quality of onion. Pre harvest foliar application of these chemicals has gained prominence and facilitates the maintenance of quality of onion bulbs on storage with respect to inhibition of sprouting, rotting and reduction in the physiological loss in weight. Therefore, the present experiment focused on the effect of foliar application of SA on plant growth, yield, disease and insect resistance and also an attempt was made to study the role of SA in post-harvest storage of onion. 


\section{MATERIALS AND METHODS}

A field trial was conducted to assess the influence of salicylic acid (SA) on the production of onion at the research farm of National Horticultural Research and Development Foundation (NHRDF), Nashik, Maharashtra, India during Rabi, 201213, 2013-14 and 2014-15 under "All India Network Research Project on Onion and Garlic". The field is situated at 20'. N latitude and $78.73^{\circ}$ 57' E longitude and 492 meter above mean sea level. The fertility status of experimental plot soil belongs to deep heavy clay with $\mathrm{pH}(7.60)$, electrical conductivity $\left(0.133 \mathrm{ds} \mathrm{m}^{-1}\right)$, organic carbon $\left(0.75 \mathrm{mg} \mathrm{g}^{-1}\right)$, available nitrogen (374.0 $\left.\mathrm{kg} \mathrm{ha}^{-1}\right)$, available phosphorus (49.05 kg ha ${ }^{1}$ ), available potassium (414.4 $\left.\mathrm{kg} \mathrm{ha}^{-1}\right)$, available sulphur $\left(19.77 \mathrm{~kg} \mathrm{ha}^{-1}\right)$, available $\mathrm{Fe}$ (14.12 $\left.\mathrm{kg} \mathrm{ha}^{-1}\right)$, available Mn (10.83 $\left.\mathrm{mg} \mathrm{kg}^{-1}\right)$, available $\mathrm{Zn}\left(0.911 \mathrm{mg} \mathrm{kg}^{-1}\right)$, available $\mathrm{Cu}\left(1.361 \mathrm{mg} \mathrm{kg}^{-1}\right)$ and available $\mathrm{B}\left(0.63 \mathrm{mg} \mathrm{kg}^{-1}\right)$. The water holding capacity at saturation was $62.8 \%$, field capacity $38.9 \%$ and permanent wilting point was $24.6 \%$ on volume basis. During experimental period of three consecutive years meteorological data are listed in Fig. 1.

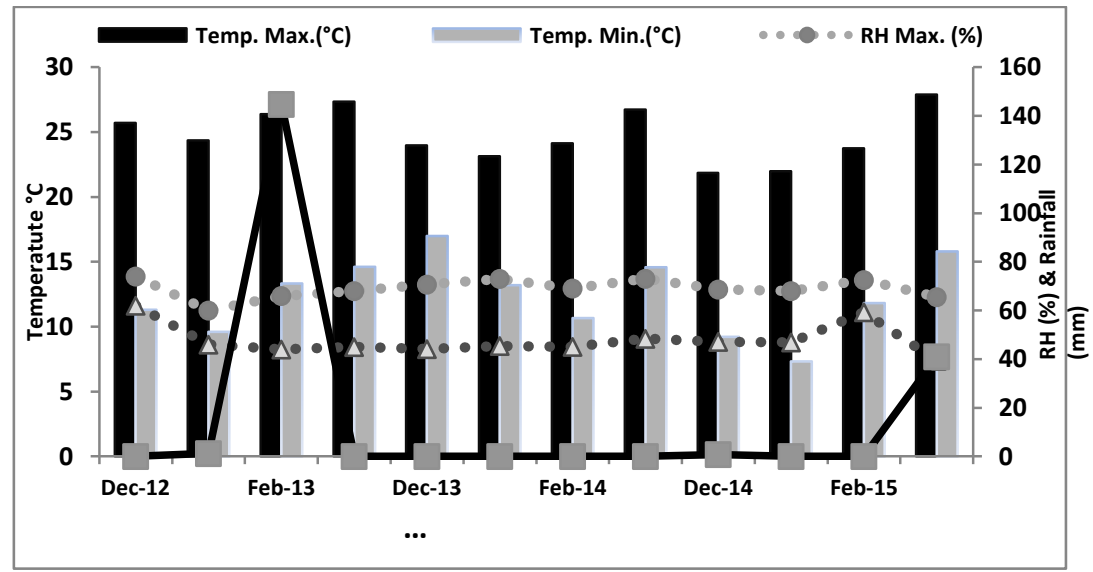

Figure 1. Agro-meteorological data during Rabi, 2012-13, 2013-14 and 2014-15 crop growing period

\section{Nursery preparation and transplanting in experimental plot}

The Agrifound Light Red onion variety developed by NHRDF were sown in the nursery beds in the month of October during three years, the size of the nursery bed was $5 \mathrm{~m}$ length, $1 \mathrm{~m}$ width and $15 \mathrm{~cm}$ height under broad based furrow system with drip irrigation system. The seeds were sown in lines at a distance of $5 \mathrm{~cm}$ at a depth of $2 \mathrm{~cm}$. The seedlings were sprayed with SA with the concentration $250 \mathrm{mg} \mathrm{lof}^{-1}$ water at 30 days after sowing (DAS), except the control plot. This concentration is more effective on onion crop has been standardized by All India Network Research Project on Onion and Garlic. About 55 days old seedling of $15-25 \mathrm{~cm}$ in height were 
transplanted in the main field with bed size $6.0 \mathrm{~m} \times 1.2 \mathrm{~m}$ laid out in Randomized Block Design in 4 replications under drip irrigation system as the method of Bhasker et al., (2018) on dated 12.12.2013 during $1^{\text {st }}$ year, 15.12.2014 during $2^{\text {nd }}$ year and 18.12.2015 during $3^{\text {rd }}$ year.

The experiment was comprised of six different treatments of SA i.e. $\mathrm{T}_{1}$-Foliar application of SA at 30 DAS and second spray at 30 days after transplanting (DAT); $\mathrm{T}_{2}$ - Foliar application of $\mathrm{SA}$ at $30 \mathrm{DAS}$ and second spray at $45 \mathrm{DAT} ; \mathrm{T}_{3}$ - Foliar application of SA at 30 DAS and second spray at $60 \mathrm{DAT}$; $\mathrm{T}_{4}-$ Foliar application of SA at 30 DAS and second spray at 30 DAT and third spray at 45 DAT; T $_{5}$ - Foliar application of SA at 30 DAS and second spray at 30 DAT and third spray at 60 DAT and $\mathrm{T}_{6}$ - Control (Water spray only).All the recommended package of practices was adapted uniformly to all the treatments as and when required. The observations were made on various growth, yield, quality, disease and insect. The bulbs were kept for post-harvest study under ambient condition for five months. The storage observations were made on physiological loss weight (PLW), sprouting, rotting and total losses.The data was recorded from 30 days after storage to 150 days and calculated as with total weight of stored bulbs, the cumulative loss in weight of bulbs were calculated and expressed as percent.

\section{RESULTS AND DISCUSSION}

\section{Influence of exogenous application of SA on morphological parameters in onion}

Exogenous spray of SA at different stages of onion significantly influenced the growth parameters as evidenced by the highest plant height and number of leaves (Table 1). Foliar application of SA three times at 30 DAS and second sprays at 30 DAT and third spray at 60 DAT increased plant height $(66.98 \mathrm{~cm})$ and number of leaves $\left(8.95\right.$ plant $\left.^{-1}\right)$ might be attributed to SA involved in increased photosynthetic activity which enhances the number of leaves per plant and chlorophyll content thereby plant growth and the results were found at par with foliar application of SA at 30 DAS and second spray at 60 DAT, and foliar application of SA at 30 DAS and second spray at 30 DAT and third spray at 45 DAT. These results are in agreement with the results of Amin et al. (2007). Similar results were obtained earlier in different crops like brinjal (Gawade and Sirohi, 2011), tomato (Niga ret al., 2017) and soybean (Nasrin et al., 2017). In untreated control lowest plant height (64.52 $\mathrm{cm})$, numbers of leaves $\left(8.68\right.$ plant $\left.^{-1}\right)$ with lowest neck thickness $(1.40 \mathrm{~cm})$ were recorded, indicating that SA played a role in increasing the growth and development of plant by enhancing SAR within the plant due to more SA accumulated by the application of SA at 30 days interval three times.

\section{Influence of exogenous application of SA on production of dry matter}

Significant influence of exogenous application of SA on dry matter yield was observed in all SA treatments as compared to control. The increase in dry weight 
might be attributed to the increase in plant height and number leaves leading to increase in photosynthetic process causing highest dry weight of leaves (13.92 q ha $\left.{ }^{1}\right)$, dry weight of bulbs (33.14 $\left.\mathrm{q} \mathrm{ha}^{-1}\right)$ and total dry biomass $\left(47.06 \mathrm{q} \mathrm{ha}^{-1}\right)$ recorded in higher rates of SA than lower rate of spraying, which might be due to better efficacy of SA in onion at higher rate of spraying which enhanced the utilization of resources and better light interception. The SA treatment also increases the TSS content as compared with control. Significantly highest TSS content $(11.96 \%)$ was recorded in SA application at 30 DAS and second spray at 30 DAT and third spray at 45 DAT and found at par with SA application at 30 DAS and second spray at 30 DAT and third spray at 60 DAT, the increase in TSS content may be due to influence on sugar metabolism in plant by increasing enzyme activity of $\alpha$ - amylase and nitrate reductase, which accelerate the sugar translocation from the leaves to economic parts of the plant (Farouk and Osman, 2011). The results are in agreement with earlier report (Bideshki et al., 2013).

\section{Influence of exogenous application of SA on pests and diseases}

Among the various foliar diseases of onion, stemphylium blight (Stemphylium vesicarium) is the most destructive diseases causing severe yield reduction. At 70 DAT the lowest stemphylium blight incidence and intensity were recorded in the treatment of SA, whereas one more destructive diseases of onion i.e. purple blotch did not appear. The incidence of stemphylium blight ranged from $9.0 \%$ to $21.0 \%$ and intensity varied between $0.36 \%$ and $0.84 \%$. The lowest disease incidence and intensity were recorded in three times SA application. Less infection of stemphylium blight was recorded in all SA treatments, induces the resistance to $S$. vesicarium than the control, which might be due to induction of disease resistance towards SAR against pathogens by more accumulation of SA (Shang et al., 2011; Wu et al., 2012). The similar results were recorded in tomato (Pandey and Gupta, 2012; Falconi et al., 2013). Thrips (Thripstabaci Linderman) is most common serious destructive pest of onion. The impact of exogenous application of SA towards onion thrips infestation under field condition at different stages of crop growth revealed significant reduction in thrips population by application of SA at three times of spraying than two times. Entire cropping period lowest mean thrips population (18.45 nymphs plant ${ }^{-1}$ ) was recorded in three times SA application, which might be due to application of second and third spray of SA at 45 and 60 DAT, effectively reduced the thrips infestation (Fig. 2) and might further induce the resistance of plants, while highest thrips population was recorded at 70 DAT in all the treatments. 


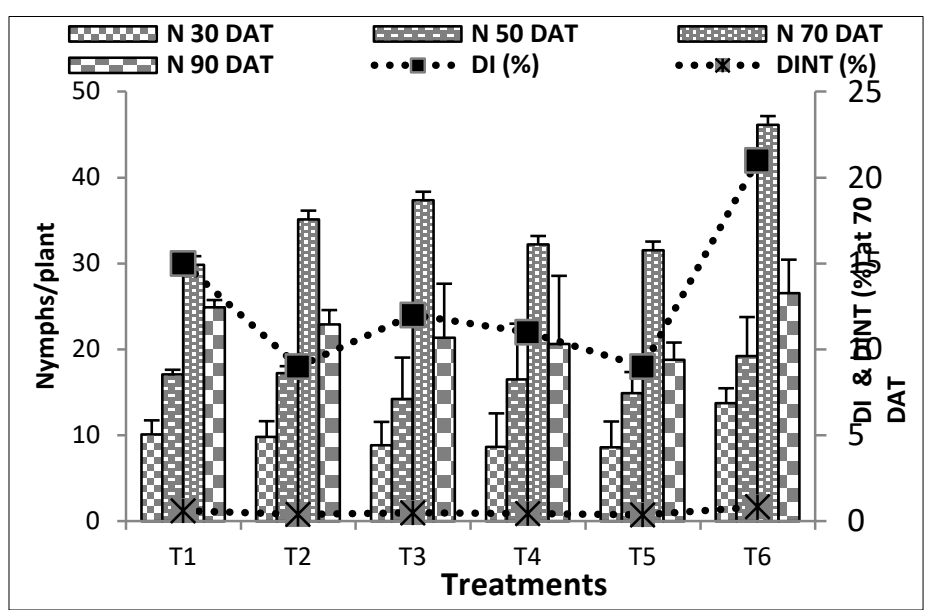

Figure 2. Effect of foliar application of salicylic acid on pest and disease reactionof onion under field conditions

* DI - Disease Incidence; DINT - Disease Intensity

\section{Influence of exogenous application of SA on yield attributing characters}

SA had significant influence on bulb growth and yield attributing parameters. The highest equatorial bulb diameter $(5.58 \mathrm{~cm})$, polar bulb diameter $(4.03 \mathrm{~cm})$ recorded in exogenous SA application with higher times, where equatorial bulb diameter was found at par with all the treatments except control. The increase in bulb size might be due to better photosynthetic efficacy with increased dry matter content of leaves and bulbs facilitating to better allocation of photosynthates from source towards the economic part of sink, hence higher gross yield $\left(304.59 \mathrm{q} \mathrm{ha}^{-1}\right)$ as well as marketable yield (271.08 $\left.\mathrm{q} \mathrm{ha}^{-1}\right)$ with highest cost: benefit ratio (1.0: 4.84) were recorded in three times SA application (Table 2). The results of highest dry matter of leaves (13.92 q $\left.\mathrm{ha}^{-1}\right)$, bulbs $\left(33.14 \mathrm{q} \mathrm{ha}^{-1}\right)$ and total dry matter $\left(47.06 \mathrm{q} \mathrm{ha}^{-1}\right)$, and lower disease and pest infestation showed positive relation with yield parameters. Due to better efficacy of SA highest a grade bulb $(4.0-6.0 \mathrm{~cm})$ i.e. $60.13 \%$, B grade bulb $(3.5-4.0 \mathrm{~cm})$ $(32.08 \%)$ and lowest $\mathrm{C}$ grade bulbs $(2.0-3.5 \mathrm{~cm})(7.85 \%)$ were recorded in three times SA application at 30 DAS and second spray at 30 DAT and third spray at 60 DAT over control. The A grade bulb showed at par results with SA application at 30 DAS and second spray at 30 DAT and third spray at 45 DAT. The grading of bulb based on size; it increases the market profit. The foliar application of SA might be due to enhanced uptake of NPKS nutrients, improved flow of photosynthesis assimilates and cell integrity which in term reflected increased bulb weight $(60.56$ g)The lowest bolting (0.35\%) was recorded in SA application at 30 DAS and second spray at 30 DAT and third spray at 45 DAT and doubles (3.35\%) in SA application at 30 DAS and second spray at 45 DAT indicates that foliar application of SA had 
significant effect on per cent reduction of bolters and doubles over the control. The results of yield parameters are in line with the results already reported in onion (Amin et al., 2007) garlic (Bideshki and Arvin, 2010) and soybean (Nasrin et al., 2017).

\section{Influence of exogenous application of SA on post-harvest storage losses}

Onion storage is one of the most important aspects for post-harvest handling. The storage quality of onion depends on the total dry matter content and total loss in weight at the time of marketing. Pre harvest application of SA towards post-harvest storage losses significantly reduced the losses (Fig. 3 a, b, c, d). During five months storage period comparatively lowest sprouting loss $(5.64 \%)$, rotting loss $(26.20 \%)$, physiological loss in weight (13.51\%) and total losses (45.36\%) were recorded in SA application at 30 DAS and second spray at 30 DAT and third spray at 60 DAT, by 30 days interval SA application enhanced SAR against disease and pest for longer time due to more accumulation of SA within the cell up to crop physiological maturity(Fig. 3e), apart from protection action of SA also associated with the reduction of transpiration rate (Singh and Usha, 2003) and the same treatment is considered one of the desirable treatments to increase storage life of onion. The treatment in which minimum loss in weight of bulb during storage is considered to be one of the desirable treatments to increase storage life of onion. The similar reports of better efficacy of SA at higher dose were reported by Noor et al. (1998) in onion and Bideshki and Arvin (2010) in garlic. Overall, the score of acceptability were highest in three times SA application.

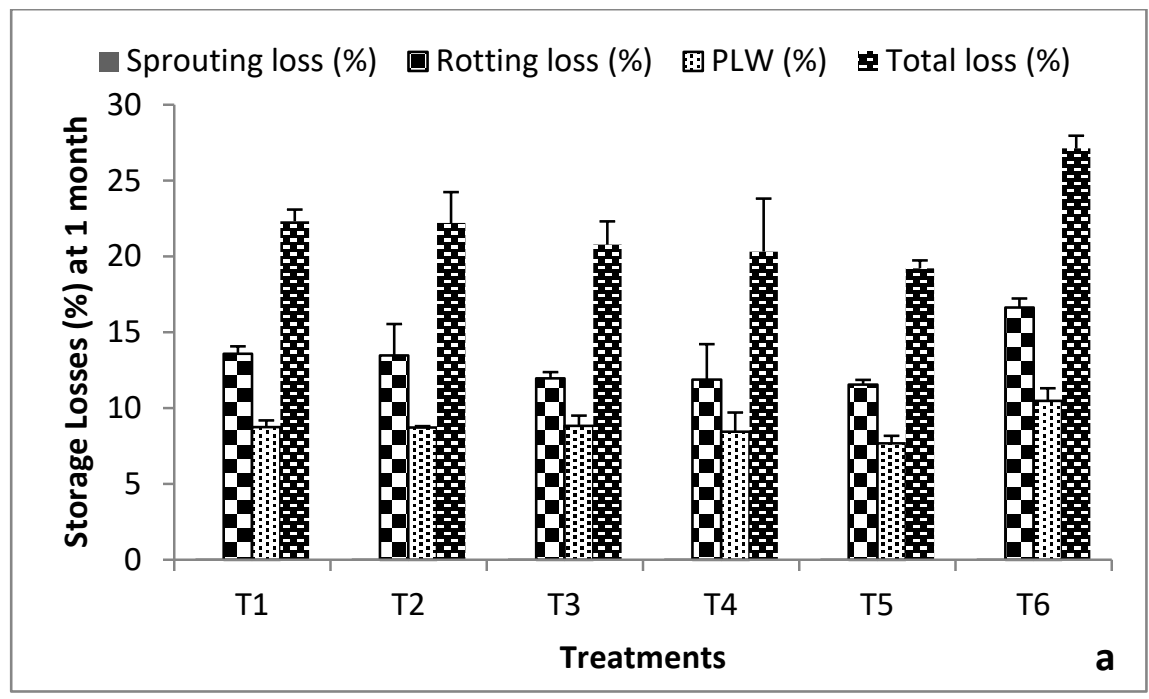



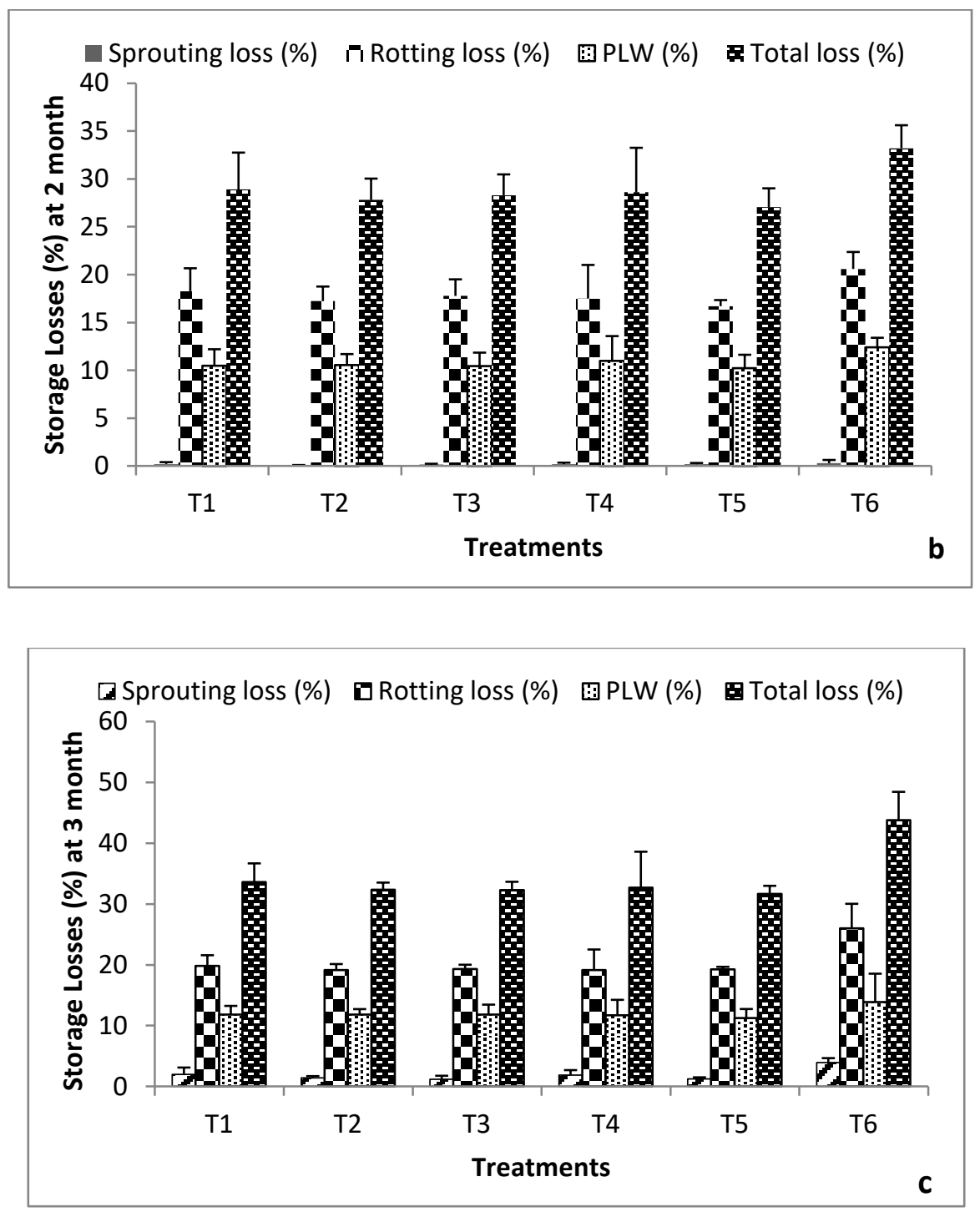

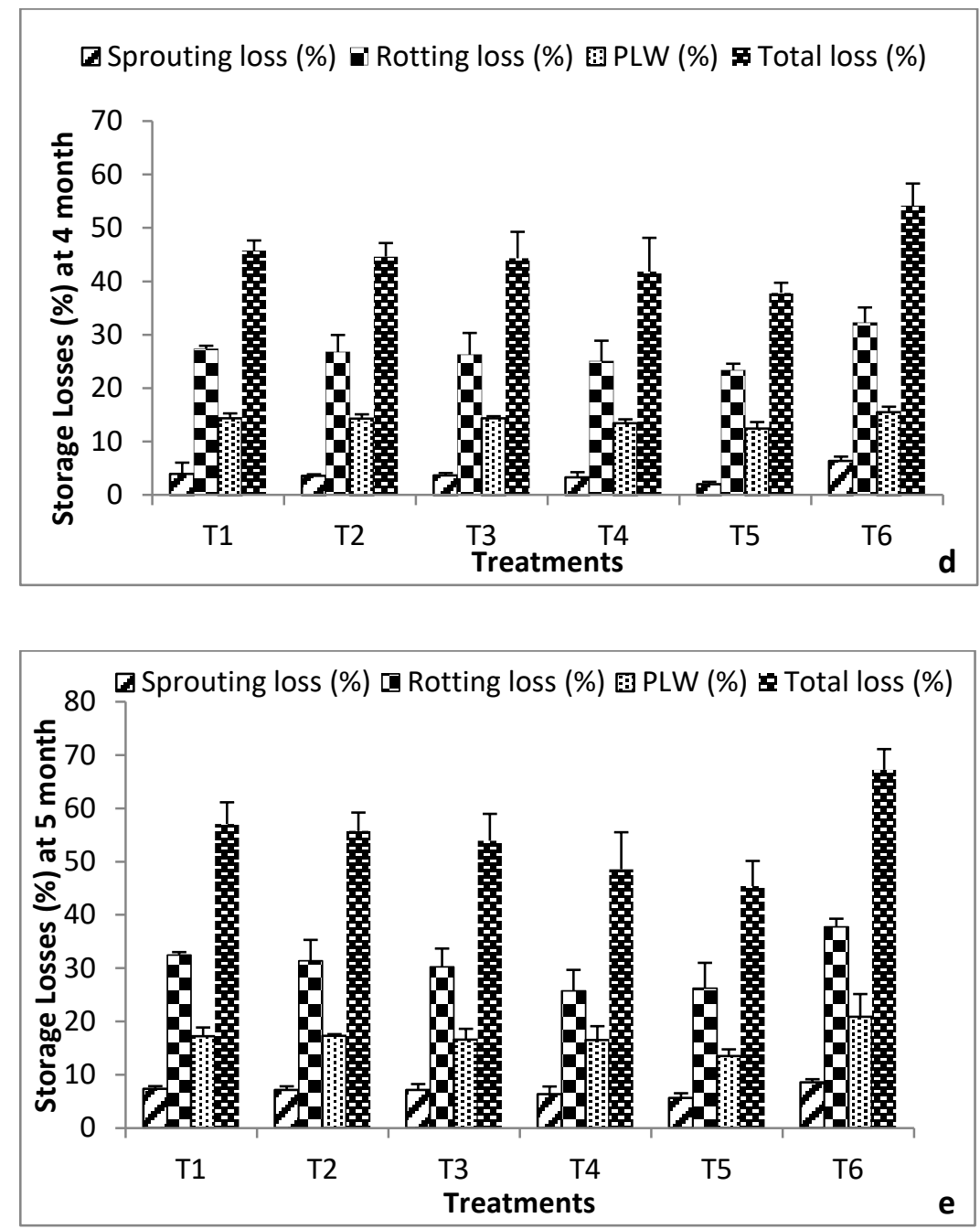

Figure 3. Effect of foliar application of salicylic acid on storage quality of onion for five months ( $a, b, c, d$ and e)

\section{CONCLUSION}

The three consecutive years study on effect of Salicylic Acid on growth, yield, quality and disease pest reaction of onion revealed that foliar application of Salicylic Acid @ $250 \mathrm{mg}^{-1}$ per liter at 30 DAS during nursery stage, subsequently $2^{\text {nd }}$ spray at 30 DAT and $3^{\text {rd }}$ spray at 60 DAT had significant positive influence on vegetative as well as bulb yield and yield attributing parameters and also minimize the loss due to disease pests in field as well as physiological loss weight, rotting and sprouting in storage condition and recorded highest good bulb recovery with highest cost: benefit values. 


\section{REFERENCES}

Amin, A.A., Rashad, M., E.L.S. and EL-Abagy, H.M.H. (2007). Physiological effect of indole-3-butyric acid and salicylic acid on growth, yield and chemical constituents of onion plants. Journal of Applied Sciences Research, 3(11):1554-1563.

Bhasker, P., Singh, R.K., Gupta, R.C., Sharma, H.P. and Gupta, P.K. (2018). Effect of drip irrigation on growth and yield of onion (Allium cepa L.). Journal of Spices and Aromatic Crops, 27 (1):32-37.

Bhasker, P., Tailor, A.K., Sharma, H.P., Singh, R.K. and Gupta, P.K. (2018). Medicinal, Nutraceutical Values and Consumption Pattern of Onion (Allium cepa) in India: An Over View". International Journal of Current Microbiology and Applied Sciences (Special Issue), 6:2629-2638.

Bideshki, A. and Arvin, M.J. (2010). Effect of salicylic acid (SA) and drought stress on growth bulb yield and allicin content of garlic (Allium sativum) in field. Plant Ecophysiology, 2:73-79.

Bideshki, A., Arvin, M.J. and Mehrnoosh, D. (2013). Interactive effect of Indole-3- butyric acid (IBA) and salicylic acid (SA) on growth parameters, bulb yield and allicin contents of garlic (Allium sativum) under drought stress in field. International Journal of Agronomy and Plant Production, 4(2):271 - 279.

Carr, J.P., Lewsey, M.G. and Palukaitis, P. (2010). Signaling in induced resistance, Virus Research, 76:57-121.

Dat, J.F., Foyer, C.H. and Scote, I.M. (1998). Changes in Salicylic acid and antioxidants during induced thermo tolerance in mustard seedlings. Plant Physiology, 118:1455-1466.

Dixon, R.A. (2001). Natural product and plant disease resistance. Nature, 411:843-847.

Falconi, T., Ferrio, J.P., Cueto, I.S.D., Gine, J., Achon, M.A. and Medina, V. (2013). Effect of salicylic acid treatment on tomato plant physiology and tolerance to potato virus $\mathrm{X}$ infection. European Journal of Plant Pathology, 138:331-345.

Farouk, S. and Osman, M.A. (2011). The effect of plant defense elicitors on common bean (Phaseolus vulgaris L.) growth and yield in absence or presence of spider mite (Tetranychus urticae Koch) infestation. Journal of Stress Physiology and Biochemistry, 7(3):5-22.

Gawade,B. and Sirohi, A. (2011). Induction of Resistance in Eggplant (Solanum melongena) by Salicylic Acid against Root-Knot Nematode, Meloidogyne incognita. Indian Journal of Nematology, 41(2):201-205.

Habibi, G. (2012). Exogenous salicylic acid alleviates oxidative damage of barley plants under drought stress. Acta Biologica Szegediensis, 56:57-63.

Hayat, Q., Hayat, S., Irfan, M. and Ahmad, A. (2009). Effect of exogenous salicylic acid under changing environment: a review. Environmental and Experimental Botany, 68(1):14-25.

He, Y. and Zhu, Z.J. (2008). Exogenous salicylic acid alleviates $\mathrm{NaCl}$ toxicity and increases antioxidative enzyme activity in Lycopersicon esculentum. Biologia Plantarum, 52:792-795. 
Kachroo, P., Yoshioka, K., Shah, J., Dooner, H.K. and Klessig, D.F. (2000). Resistance to turnip crinkle virus in Arabidopsis is regulated by two host genes and is salicylic acid dependent but NPR1, ethylene, and jasmonate independent. Plant Cell, 12:677-690.

Khan, W., Prithiviraj, B. and Smith, D.L. (2003). Photosynthetic responses of corn and soybean to foliar application of salicylates. Journal of Plant Physiology, 160:485-492.

Miura, K. and Tada, Y. (2014). Regulation of water, salinity, and cold stress responses by salicylic acid. Frontiers in Plant Science, 5:1-12.

Nasrin, R., Ali, E., Jahanfar, D. and Soodabeh, J. (2017). Salicylic acid induced changes on antioxidant capacity, pigments and grain yield of soybean genotypes in water deficit condition. Journal of Plant Interaction, 12(1):457-464.

Nazar, R., Iqbal, N., Syeed, S. and Khan, N.A. (2011). Salicylic acid alleviates decreases in photosynthesis under salt stress by enhancing nitrogen and sulfur assimilation and antioxidant metabolism differentially in two mungbean cultivars. Journal of Plant Physiology, 168:807-815.

Nazara, R., Umara, S., Khanb, N.A. and Sareera, O. (2015). Salicylic acid supplementation improves photosynthesis and growth in mustard through changes in proline accumulation and ethylene formation under drought stress. South African Journal of Botany, 98:84-94.

Nigar, A., Islam, M.M., Hossain, M.E., Nizam, R., Monalesa, N., Hussain, Md. A. and Parvin, S. (2017). Response of Tomato (Solanum lycopersicum L.) to Salicylic Acid and Calcium. Journal of Applied Life Sciences International, 15(2):1-7.

Noor, B., Izhar, A. and Mati, U.R. (1998). Post-harvest application of salicylic acid to onion bulbs for sprout inhibition. Sarhad Journal of Agriculture, 14(6):541-547.

Pandey, K.K. and Gupta, R.C. (2012). Management of fusarium wilt of tomato by application of bioagents and salicylic acid. Indian Phytopathology, 65(1):94-96.

Shama, M.A., Moussa, S.A.M., Abo, El. and Fade, N.I. (2016). Salicylic acid efficacy on resistance of garlic plants (Allium sativum, L.) to water salinity stress on growth, yield and its quality. Alexandria Science Exchange Journal, 37(2):165-174.

Shang, J., Xi, D.H., Jia, S.D., Zhang, Z.W., Yuan, S. and Lin, H.H. (2011). A broad spectrum, efficient and non-transgenic approach to control plant viruses by application of Salicylic Acid and Jasmonic Acid. Planta, 233:299-308.

Singh, B. and Usha, K. (2003). Salicylic acid induced physiological and biochemical changes in wheat seedlings under water stress. Plant Growth Regulation, 39:137-141.

Vlot, A.C., Dempsey, D.A. and Klessig, D.F. (2009). Salicylic acid, a multifaceted hormone to combat disease. Annual Review of Phytopathology, 47:177-206.

Wu, W., Ding, Y., Wel, W. and Davis, R.E. (2012). Salicylic acid-mediated elicitation of tomato defence against infection by potato purple top phytoplasma. Annals of Applied Biology, 161:36-45.

Zhang, B., Ma, R., Guo, L., Song, Z. and Yu, M. (2017). Effects of exogenous salicylic acid on physiological traits and CBF gene expression. Zoology Research, 3 (1):118-122 